\title{
Virulencia de cepas de Listeria monocytogenes procedentes de cabras y sus derivados
}

\section{Virulence of Listeria monocytogenes strains from goats and their byproducts}

\author{
Guicela Ramírez Bernala, Alma Virginia Lara Sagahóna, Carlos Gerardo García Tovara, \\ Efrén Díaz Apariciob, Víctor Rubén Tenorio Gutiérrezb
}

\begin{abstract}
RESUMEN
Se evaluó la virulencia de cepas de Listeria monocytogenes todas de serotipo 4 b procedentes de cabras y sus derivados. Se observaron niveles de virulencia variables cuando se comparó la virulencia relativa (porcentaje de letalidad) en ratones BALB/c inoculados vía intravenosa o intragástrica y su capacidad para infectar macrófagos J 774A.1, y células epiteliales Caco-2. Dos cepas obtenidas de alimento de cabras produjeron $100 \%$ de letalidad por ambas vías de inoculación y no mostraron diferencia significativa con la cepa testigo $(P>0.05)$ respecto al porcentaje de invasión y a los parámetros de la cinética de crecimiento cuadrática observada en ambas líneas celulares. Si bien todas las cepas lograron invadir las células Caco-2, solamente algunas consiguieron invadir el bazo después de la inoculación por vía intragástrica. Las dos cepas provenientes de alimento de cabras fueron las más virulentas, representando un riesgo para la salud humana y animal, ya que pueden ser diseminadas en el hato y de este a otras explotaciones o a las instalaciones donde se elaboran alimentos.
\end{abstract}

PALABRAS CLAVE: Listeria monocytogenes, Cabras, Virulencia, Ratones BALB/ c, Crecimiento intracelular, Macrófagos J774A.1, Caco-2.

\begin{abstract}
The virulence of 12 Listeria monocytogenes strains from goat and goat by-products was evaluated. Variable virulence levels were found when compared the relative virulence (mortality, \%) and the ability to grow infect the spleen of BALB/ c mice inoculated intravenously or intragastrically. Two strains from feed produced $100 \%$ mortality, by either inoculation route and seven strains, including those from feed, infected the spleen with both inoculation routes. A strain inoculated intravenously without causing death in the mice produced spleen counts similar to those obtained in dead mice, this could indicate that a high count of the microorganism in the spleen not necessarily ensures its virulence. We also tested the capacity to infect J 774 macrophages and Caco-2 epithelial cells, finding higher invasion and intracellular growth in Caco-2 with respect the macrophages and showing quadratic growth kinetics in both cell lines. Only the two feed strains did not show a significant difference from the control strain $(P>0.05)$ regarding kinetic parameters and invasion percentage in both cell lines. Although all isolates were able to invade Caco- 2 cells, not all isolates were able to invade the spleen after the intragastrically inoculation. Two goats feed strains were the most virulent, representing a risk for animal and human health.
\end{abstract}

KEY WORDS: Listeria monocytogenes, Goats, Virulence, BALB/c mice, I ntracellular growth, Macrophages J774, Caco-2.

Listeria monocytogenes es un patógeno bacteriano transmitido por alimentos, que causa la listeriosis en humanos y animales. Las
Listeria monocytogenes is a food-borne pathogen that causes listeriosis in humans and animals. The clinical signs of listeriosis include:

\footnotetext{
Recibido el 29 de enero de 2013. Aceptado el 30 de abril de 2013.

a Facultad de Estudios Superiores Cuautitlán, UNAM. México.

b Laboratorio de Bacteriología, Centro Nacional de Investigación Disciplinaria en Microbiología Animal, INIFAP. Km 15.5 Carretera México-Toluca, Col. Palo Alto, Cuajimalpa DF. México. Tel. (0155) 36180800. tenorio.victor@inifap.gob.mx. Correspondencia al último autor.

Trabajo financiado por SAGARPA clave del proyecto 46599; CONACYT clave del proyecto SIN-2008/90945 y beca CONACYT número 173630.
} 
características clínicas de la listeriosis incluyen meningitis, meningoencefalitis, septicemia, aborto y gastroenteritis $(1,2)$. Aunque su incidencia es baja, tiene un impacto sanitario y económico considerable debido a su letalidad (20 a $30 \%$ ), y a que aproximadamente el $93 \%$ de los casos requiere hospitalización $(3,4)$. L. monocytogenes es responsable de aproximadamente $21 \%$ de las muertes en EE.UU. relacionadas con los principales patógenos transmitidos comúnmente por alimentos $(3,4)$. Un total de 1,624 casos confirmados de listeriosis fueron reportados en 28 países miembros de la comunidad europea en 2010; el índice listeriosis fue estable durante 2006-2010, aunque en algunos países se produjo un incremento en ese mismo periodo(5,6).

La mayoría de los casos de listeriosis en animales han sido reportados en rumiantes de granja. La leche y los productos lácteos han sido involucrados frecuentemente en brotes de listeriosis en humanos $(7,8)$. Mientras que las granjas posiblemente sirvan como fuentes directas 0 indirectas de cepas de L. monocytogenes que son introducidas en la cadena de alimentación humana, éstas también representan ecosistemas que podrían facilitar el surgimiento de subtipos nuevos y más virulentos de este patógeno en un ambiente de alta frecuencia de transmisión(9). La importancia de las cabras como proveedoras de alimentos se ha reflejado en el incremento de la población caprina y la producción de sus derivados $(10,11)$. A pesar de la significativa función socioeconómica de la cría de esta especie animal en todo el mundo, la investigación en cabras es limitada en comparación con la investigación en otras especies de animales y sus sistemas de producción $(12,13)$. En México ya ha sido detectada la presencia de Listeria en leche y quesos(14,15), sin embargo es escasa la información relacionada con cepas aisladas de cabras y sus derivados así como la virulencia de los mismos(16,17).

Se ha observado una heterogeneidad considerable en los niveles de virulencia de las meningitis, meningoencephalitis, septicemia, abortion and gastroenteritis $(1,2)$. Although its incidence is low, it has a substantial health and economic impact due to its high fatality rates (20 to $30 \%$ ) and approximately $93 \%$ of cases require hospitalization $(3,4)$. L. monocytogenes is the causative agent of $21 \%$ of deaths in the United States of America, associated with the main food-borne pathogens $(3,4)$. In 2010, a total of 1,624 confirmed cases of listeriosis were reported in 28 member countries of the European Community; listeriosis rate was stable throughout 2006-2010, although in some countries there was an increase during the same time period $(5,6)$.

The majority of listeriosis cases in animals have been reported in farmed ruminants. Milk and dairy products have been frequently implicated in listeriosis outbreaks involving people $(7,8)$. Whereas farms are probably direct or indirect sources of $\mathrm{L}$. monocytogenes strains that are introduced into the human food chain, these also represent ecosystems that could facilitate the emergence of new and more virulent pathogen subtypes in an environment of high frequency transmission(9). The importance of goats, as potential sources for food, has been reflected in the increase of caprine population and their by-products $(10,11)$. Despite the significant socioeconomic function of raising this species throughout the world, research in goats is limited in comparison with research in other animal species and their production systems $(12,13)$. In Mexico, L. monocytogenes has been detected in milk and cheese $(14,15)$; however, there is limited information related to strains isolated from goats and their by-products, as well as its virulence $(16,17)$.

A substantial heterogeneity in virulence level of L. monocytogenes strains has been observed, without any systematic correlation established between virulence level and specific origin or identification characteristics $(18,19)$. It is well established that the immune response of people or the ingested pathogen dose play an important role in invasive or gastroenteric pathologies. 
cepas de L. monocytogenes sin alguna correlación sistemática establecida entre el nivel de virulencia y las características de identificación u origen específicas(18,19). Está bien establecido que la respuesta inmune de las personas o la dosis del patógeno ingerida, juegan un papel importante en las presentaciones invasivas o gastroentéricas. Las diferencias entre la virulencia de las cepas también podrían contribuir a las diversas manifestaciones clínicas(20).

Los principales métodos para evaluar la virulencia de Listeria monocytogenes incluyen ensayos in vivo en animales y ensayos in vitro con células $(21,22,23)$. La penetración a través de la barrera intestinal es el paso primario para la infección y la subsiguiente invasión de los órganos blanco (hígado y bazo), que es crítica para el establecimiento de la infección sistémica. Los ensayos in vitro están basados en la capacidad de este patógeno para adherirse, entrar, multiplicarse en el citosol y diseminarse en diversas líneas de células eucariotas(20). El objetivo de este trabajo fue evaluar la virulencia de cepas de Listeria monocytogenes procedentes de alimento, materia fecal, leche y queso de cabras, mediante la determinación de su virulencia relativa en ratón y el crecimiento intracelular en células epiteliales y macrófagos.

Bacterias: Se compararon 12 cepas de L. monocytogenes pertenecientes al serotipo $4 b(24,25)$, de las cuales 3 fueron obtenidas de alimento de cabra (AC), 1 de leche de cabra (LC), 3 de materia fecal de cabra (MFC) y 5 de queso de cabra (QC). Además se empleó como testigo una cepa de L. monocytogenes ATCC 43249 serotipo 1/2a (LMC1) y una cepa de serotipo 4b (LMC2) donada por el hospital Manuel Gea González (SSA). Las cepas se cultivaron en caldo BHI (Difco) a $37^{\circ} \mathrm{C}$ en agitación (180 rpm) y se mantuvieron almacenadas en caldo BHI suplementado con glicerol y suero bovino (1:1:1) a $-70{ }^{\circ} \mathrm{C}$ hasta su uso.

Ratones. Ciento ochenta (180) ratones BALB/c de 4 o 10 semanas de edad obtenidos del
The differences between the virulence of strains could also contribute to several clinical manifestations(20).

The main methods for evaluating virulence of L. monocytogenes include: animal testing and in vitro cell based assays $(21,22,23)$. Penetration through the epithelial intestinal barrier is the main step for infection and subsequent invasion of target organs (liver and spleen), which is critical for the establishment of systemic disease. In vitro assays are based on the capacity of this pathogen to adhere, enter, multiply within the cytosol and spread to diverse eukaryotic cell lines(20). The objective of this study was to evaluate the virulence of $L$. monocytogenes from food, faeces, goat milk and cheese, by determination of its relative virulence in mice and intracellular growth in epithelial cells and macrophages.

Bacteria. Twelve L. monocytogenes serotype $4 b(24,25)$ strains were compared, of which 3 were obtained from goat food (AC), 1 from goat milk (LC), 3 from goat faeces (MFL) and 5 from goat cheese (QC). Additionally, a strain of L. monocytogenes serotype 1/2a (ATCC 43249) (LMC1) and a strain of $L$. monocytogenes serotype $4 b$ (LMC2), donated by the Hospital General Dr. Manuel Gea González, were used as control. Strains were cultivated in brain-heart infusion broth (BHIB) (Difco), incubated at 37 ${ }^{\circ} \mathrm{C}$ with agitation (180 rpm) and stored in BHIB supplemented with glycerol and bovine serum (1:1:1) at $-70{ }^{\circ} \mathrm{C}$ until used.

Mice. A hundred and eighty, (180) 4 to $10 \mathrm{wk}$ old BALB/c mice obtained from the Bioterio del Centro Médico Nacional Siglo XXI (IMSS) were used to make passages and be infected. Mice were allowed to acclimatize for $2 \mathrm{wk}$ and were fed autoclaved food and water ad libitum. Care and handling procedures were carried according to guidelines of the Norma Oficial Mexicana NOM-062-ZOO-1999 and Subcomité I nstitucional para el Cuidado de Animales de Eperimentación (SICUAE) of the Facultad de Medicina Veterinaria y Zootecnia of the Universidad Nacional Autónoma de México. 
Bioterio del Centro Médico Nacional Siglo XXI (IMSS), se emplearon para el pase e infección. Se permitió que los ratones se aclimataran durante dos semanas y se alimentaron con agua y alimento estériles ad libitum. Su cuidado y manejo se llevó a cabo de acuerdo a los procedimientos indicados por la Norma Oficial Mexicana NOM-062-ZOO-1999 y el Subcomité Institucional para el Cuidado de Animales en Experimentación (SICUAE) de la Facultad de Medicina Veterinaria y Zootecnia de la UNAM.

Pase en Ratón. Dos ratones BALB/C de 12 semanas de edad fueron inoculados por vía intraperitoneal con $\mathrm{H}^{\prime \prime} 10^{7}$ unidades formadoras de colonia (ufc) de cada una de las cepas de L. monocytogenes evaluadas en fase de crecimiento logarítmica. Se utilizó como testigo negativo un grupo de ratones inoculado con solución salina fisiológica ( $\mathrm{NaCl} 0.15 \mathrm{mM})$. El tamaño del inóculo fue confirmado por conteo de ufc en placas de agar BHI (Difco). Tres días después de la inoculación, las bacterias se aislaron de los ratones. Los bazos se homogeneizaron en $1 \mathrm{ml}$ de solución salina fisiológica y diluciones de estos homogeneizados se sembraron e incubaron en placas de agar $\mathrm{BHI}$ (Difco) a $37^{\circ} \mathrm{C}$ durante $48 \mathrm{~h}(26)$. Las cepas obtenidas fueron confirmadas mediante siembra en placas de agar Oxford (Difco), tinción Gram y PCR(27). Las cepas se cultivaron y almacenaron como ya se describió.

Células. Se emplearon las líneas celulares de macrófagos J 774A.1 y de células epiteliales Caco- 2 adquiridas de la American Type Culture Collection (ATCC). Ambas líneas celulares fueron crecidas en medio DMEM (Dulbecco's modified Eagle's medium) suplementado con 20/10 \% (vol/vol) de suero fetal bovino según fuesen las células J774A.1 o Caco-2 respectivamente (inactivado $30 \mathrm{~min}$ a $56{ }^{\circ} \mathrm{C}$ ), aminoácidos no esenciales $(0.1 \mathrm{mM})$ y penicilina-estreptomicina (100 IU/ml: ìg/ml) excepto en los ensayos de crecimiento intracelular (Invitrogen). Las células se mantuvieron en incubadora a $37^{\circ} \mathrm{C}$ y con $5 \%$ de $\mathrm{CO}_{2}$.
Mouse passage. Two, 12-wk-old BALB/C mice were inoculated by peritoneal route with $\mathrm{H}^{\prime \prime} 10^{7}$ colony forming units (cfu) of each L. monocytogenes strains evaluated during log phase. A group of mice inoculated with physiological saline solution ( $\mathrm{NaCl} 0.15 \mathrm{mM}$ ) was used as negative control. The inoculum size was confirmed by cfu plate count using $\mathrm{BHI}$ agar. Three days after inoculation, bacteria were isolated from mice. Spleens were homogenized in $1 \mathrm{ml}$ of physiological saline solution and the dilutions of these homogenizers were plated onto $\mathrm{BHI}$ agar (Difco) and incubated at $37{ }^{\circ} \mathrm{C}$ for $48 \mathrm{~h}^{(26)}$. The strains obtained were confirmed by using seeded Oxford agar plates (Difco), Gram stain and PCR(27). Strains were cultured and stored as aforementioned.

Cells. Macrophage-like J774A.1 cell line and epithelial Caco-2 cell line obtained from the American Type Culture Collection (ATCC) were used. Both cell lines were grown in DMEM medium (Dulbecco's modified Eagle's medium) supplemented with $20 / 10 \%$ ( $\mathrm{vol} / \mathrm{vol}$ ) of foetal bovine serum according to J 774A. 1 or Caco-2 cells, respectively (inactivated for $30 \mathrm{~min}$ at 56 $\left.{ }^{\circ} \mathrm{C}\right)$, non-essential amino acids $(0.1 \mathrm{mM})$ and penicillin-streptomycin (100 lU/ml: $\mu \mathrm{g} / \mathrm{ml}$ ), except in intracellular growth assays (Invitrogen). Cells were incubated at $37^{\circ} \mathrm{C}$ with $5 \% \mathrm{CO}_{2}$.

Virulence in BALB/C mice. For the evaluation of relative virulence in $\mathrm{L}$. monocytogenes strains for each inoculation route, intravenous (iv) and intragastric (ig), and for each strain, a group of five, 6-wk-old BALB/c mice were used. Microorganism cultures in log phase, centrifuged, washed and resuspended in physiological saline solution were used. Mice were inoculated via intravenous tail vein with $0.2 \mathrm{ml}\left(\mathrm{H}^{\prime \prime} 10^{5} \mathrm{cfu}\right)$ of the culture, using a $1 \mathrm{ml}$ syringe (Becton Dickinson needle $27 \mathrm{G} \times 13 \mathrm{~mm}$ ). Mice inoculated by intragastric route were withdrawn from food $12 \mathrm{~h}$ before infection, with the aim to avoid risk of vomiting during or after inoculation. They were inoculated with $0.1 \mathrm{ml}$ $\left(\mathrm{H}^{\prime \prime} 10^{9} \mathrm{cfu}\right)$ of culture via intragastric stainless 
Virulencia en ratones BALB/c. Para la evaluación de la virulencia relativa de las cepas de L. monocytogenes por cada vía de inoculación, intravenosa (iv) e intragástrica (ig), por cada cepa se empleó un grupo de cinco ratones $\mathrm{BALB} / \mathrm{c}$ de 6 semanas de edad. Se utilizaron cultivos del microorganismo en fase de crecimiento logarítmica, centrifugados, lavados y resuspendidos en solución salina fisiológica. La inoculación intravenosa se hizo en la vena caudal con $0.2 \mathrm{ml}$ (H"105 ufc) del cultivo empleando una jeringa de $1 \mathrm{ml}$ (longitud de aguja $13 \mathrm{~mm} /$ calibre 27Gx Becton Dickinson). A los ratones inoculados por la vía intragástrica se les retiró el alimento $12 \mathrm{~h}$ previas a la inoculación, con el fin de evitar el riesgo del vómito durante o posterior a la inoculación. Se inocularon con $0.1 \mathrm{ml}$ (H"109 ufc) del cultivo vía intragástrica mediante una sonda de alimentación de acero inoxidable (calibre 22, longitud 1.5 in) conectada a una jeringa de 1 $\mathrm{ml}$. Se utilizó como testigo negativo un grupo de ratones inoculado con solución salina por cada una de las vías (iv e ig). El tamaño del inóculo se verificó mediante conteo de ufc en placas de agar BHI (Difco), después de incubación a $37{ }^{\circ} \mathrm{C}$ durante $48 \mathrm{~h}(23,26)$. Los ratones se observaron durante 7 días. Los ratones que sobrevivieron se sacrificaron mediante la aplicación de $\mathrm{CO}_{2}$ seguida de dislocación cervical. Se extrajo el bazo de todos los ratones muertos o sacrificados de cada grupo y se realizaron los conteos del microorganismo de prueba que logró invadirlos. Los bazos se homogeneizaron en $1 \mathrm{ml}$ de solución salina fisiológica, y diluciones de estos homogeneiza-dos fueron sembrados e incubados en placas de agar BHI (Difco) a $37^{\circ} \mathrm{C}$ durante $48 \mathrm{~h}$. Las cepas aisladas se confirmaron mediante siembra en placas de agar Oxford (Difco), tinción Gram y PCR(27). La virulencia relativa expresada como porcentaje de letalidad se calculó dividiendo el número de ratones muertos entre el número de ratones empleados por cepa, usando los datos de letalidad de las cepas testigo como punto de referencia(23).

Crecimiento intracelular en macrófagos $\mathrm{J} 774$ y células epiteliales Caco-2. Se crecieron steel feeding tube (22 gauge and about 1.5 inches in length) connected to $1 \mathrm{ml}$ syringe. A group of mice inoculated with saline solution either by intravenous or intragastric route (iv and ig) were used as negative control. After incubation at $37^{\circ} \mathrm{C}$ for $48 \mathrm{~h}$, the inoculum size was verified by cfu/plate count using $\mathrm{BH}$ agar (Difco) $(23,26)$. Mice were observed for $7 \mathrm{~d}$. Those who survived were euthanized using $\mathrm{CO}_{2}$ followed by cervical dislocation. The spleen was removed from all dead and euthanized mice and test microbial count was conducted. The spleens were homogenized in $1 \mathrm{ml}$ of physiological saline solution and dilutions of these were plated and incubated in $\mathrm{BH}$ agar (Difco), at $37^{\circ} \mathrm{C}$ for $48 \mathrm{~h}$. The isolated strains were confirmed by Oxford agar seeded plates (Difco), Gram stain and PCR(27). The relative virulence expressed as lethal percentage was calculated dividing the number of dead mice between the number of mice used per strain, using the lethality data of the control strains as reference point(23).

Intracellular growth in macrophage-like cell line J 774 and epithelial cell line Caco-2. Monolayers of $J 774$ cells and Caco-2 epithelial cells were grown at $37^{\circ} \mathrm{C}$ for 3 and $5 \mathrm{~d}$, respectively, on 6 -well culture tissue plates until obtaining a confluence of $95 \%$ ( $\mathrm{H}^{\prime \prime} 10^{5}$ cells/well). The monolayers were inoculated with the microorganism evaluated in log phase at a concentration of $\mathrm{H}^{\prime \prime} 10^{5}$ cfu per well, obtaining a multiplicity of infection (MOI) $\mathrm{H}^{\prime \prime} 10$ bacteria per cell in DMEM medium and incubating at 37 ${ }^{\circ} \mathrm{C}$ for $1 \mathrm{~h}$; after this time, they were washed three times with phosphate buffer solution (PBS) and were incubated for $2 \mathrm{~h}$ at the same temperature in DMEM medium supplemented with gentamycin $(100 \mu \mathrm{g} / \mathrm{ml}$ of medium). Subsequently, the monolayers were washed with PBS and, in order to determine the intracellular growth, they were incubated at the same temperature in DMEM medium with gentamycin $(10 \mu \mathrm{g} / \mathrm{ml}$ of medium) for 72 additional hours. It was considered that counts obtained $2 \mathrm{~h}$ after infection represented the number of bacteria that had been internalized. The invasion 
monocapas de macrófagos $\mathrm{J} 774$ y células epiteliales Caco- 2 a $37{ }^{\circ} \mathrm{C}$ durante 3 y 5 días respectivamente, en placas para cultivo celular de seis pozos hasta obtener una confluencia de $95 \%$ (H"105 células/pocillo). Las monocapas se inocularon con el microorganismo evaluado en fase de crecimiento logarítmica a una concentración de H"106 ufc por pozo, obteniéndose una multiplicidad de infección (MOI) H"10 bacterias por célula en medio DMEM e incubadas a $37{ }^{\circ} \mathrm{C}$ durante $1 \mathrm{~h}$; transcurrido este tiempo se lavaron tres veces con buffer de fosfatos (PBS) y se incubaron $2 \mathrm{~h}$ a la misma temperatura en medio DMEM suplementado con gentamicina (100 $\mu \mathrm{g} / \mathrm{ml}$ de medio). Posteriormente, se lavaron las monocapas con PBS y para determinar el crecimiento intracelular, se incubaron a la misma temperatura en medio DMEM con gentamicina ( $10 \mu \mathrm{g} / \mathrm{ml}$ de medio) durante 22 h más. Se consideró que los conteos obtenidos $2 \mathrm{~h}$ posteriores a la infección representaron el número de bacterias que habían sido internalizadas. La invasión fue calculada en base a la relación entre las bacterias internalizadas respecto al inóculo y expresada en porcentaje. El crecimiento intracelular fue evaluado después de una incubación a $37{ }^{\circ} \mathrm{C}$ durante $2,4,8$ y $24 \mathrm{~h}$ después de la infección. Los ensayos se realizaron por duplicado y el experimento se repitió dos veces para cada cepa evaluada $(28,29,30)$.

Análisis estadístico. Para el análisis estadístico se utilizó el software R versión 2.14(31). Se realizó un análisis de regresión para ajustar un modelo a las cinéticas de crecimiento y un análisis de varianza para la comparación de los modelos de las cepas evaluadas con el control. La prueba de Dunnet se empleó para comparar el porcentaje de invasión de las cepas y su crecimiento en $24 \mathrm{~h}$ con el testigo.

En este trabajo se encontró que la virulencia relativa en ratones $B A L B / C$ varió entre las 12 cepas probadas, obteniéndose diversos porcentajes de letalidad ( 100 a $0 \%$ ) en ambas vías de inoculación. En ningún caso, pase y was calculated based on the relationship between the internalized bacteria in respect of the inoculum and expressed in percentage. The intracellular growth was evaluated after incubation at $37{ }^{\circ} \mathrm{C}$ for $2,4,8$ and $24 \mathrm{~h}$ postinfection. Assays were performed in duplicate and the experiment was repeated twice for each evaluated $\operatorname{strain}(28,29,30)$.

Statistical analysis. For the statistical analysis, software $\mathrm{R}$ version 2.14 was used(31). A regression analysis was used to fit a growth kinetic model and an ANOVA to compare the two evaluated strain models with the control. The Dunnett's test was used to compare the rate of invasion of strains and their growth in $24 \mathrm{~h}$ with the control.

In this study it was found that the relative virulence in $B A L B / C$ mice varied between the 12 tested strains, obtaining diverse lethal percentages (100 to $0 \%$ ) in both inoculation routes. In neither case, passage nor virulence assay, the evaluated organisms could be isolated from negative control spleens of mice (inoculated with physiological saline solution).

Table 1 shows the distribution of the relative virulence of strains with regard to the source. Eleven strains produced the same lethal percentage in both inoculation routes; however, the control strains (LMC1 and LMC2) and one from alfalfa (AC3) produced $100 \%$ lethality when inoculated intravenously, but not by intragastric route, where they showed a lethality of 0 to $20 \%$. Two strains ( $16.7 \%$ ) from alfalfa showed $100 \%$ lethality in both inoculation routes and six strains (50\%) did not caused death in mice irrespective of inoculation route (iv or ig). Seven out of 12 strains and two control strains invaded and grew in the spleen of mice in different proportions in both inoculation routes. I ntravenously inoculated mice (5.09 $\pm 1.98 \log _{10} \mathrm{cfu}$ ) and dead mice (7.52 \pm $0.41 \log _{10} \mathrm{cfu}$ ) had higher counts in spleen with regard to the observed in mice inoculated by intragastric route $\left(3.04 \pm 2.70 \log _{10} \mathrm{cfu}\right)$ and the euthanized $\left(2.98 \pm 2.12 \log _{10} \mathrm{cfu}\right)$. All 
VIRULENCIA DE CEPAS DE Listeria monocytogenes PROCEDENTES DE CABRAS Y SUS DERIVADOS

Cuadro 1. Virulencia relativa expresada como porcentaje de letalidad y los conteos de ufc posteriores a la inoculación intravenosa (IV) o intragástrica (IG) en ratones BALB/c, de doce cepas de $L$. monocytogenes aisladas de cabras y sus derivados

Table 1. Relative virulence expressed as percentage of lethality and cfu/plate counts after intravenous (IV) or intragastric (IG) inoculation in BALB/C mice, of $12 \mathrm{~L}$. monocytogenes strains isolated from goats and their by-products

\begin{tabular}{|c|c|c|c|c|c|}
\hline \multirow[b]{2}{*}{ Strain } & \multirow[b]{2}{*}{ Source } & \multicolumn{2}{|c|}{ Lethality (\%) } & \multicolumn{2}{|c|}{$\log _{10}$ CFU \pm SD Spleen } \\
\hline & & IV & IG & IV & IG \\
\hline LMC1 & Control & 100 & 0 & $7.52 \pm 7.1$ & $5.30 \pm 5.5$ \\
\hline LMC2 & Control & 100 & 20 & $7.79 \pm 6.9$ & $6.23 \pm 6.6$ \\
\hline AC1 & Food & 100 & 100 & $7.85 \pm 7.0$ & $7.41 \pm 6.2$ \\
\hline AC2 & Food & 100 & 100 & $7.76 \pm 7.3$ & $7.65 \pm 7.7$ \\
\hline AC3 & Food & 100 & 0 & $7.59 \pm 7.0$ & $4.50 \pm 4.2$ \\
\hline LC1 & Milk & 0 & 0 & $3.02 \pm 3.1$ & -- \\
\hline MFC1 & Faeces & 0 & 0 & $3.54 \pm 3.3$ & -- \\
\hline MFC2 & Faeces & 40 & 20 & $7.32 \pm 7.5$ & $6.10 \pm 6.4$ \\
\hline MFC3 & Faeces & 0 & 0 & $7.38 \pm 7.3$ & -- \\
\hline QC1 & Milk & 0 & 0 & $3.73 \pm 3.6$ & 一- \\
\hline QC2 & Cheese & 0 & 0 & $3.70 \pm 3.5$ & - \\
\hline QC3 & Cheese & 40 & 20 & $7.34 \pm 7.4$ & $5.99 \pm 6.3$ \\
\hline QC4 & Cheese & 0 & 0 & $3.91 \pm 3.5$ & $2.73 \pm 2.4$ \\
\hline QC5 & Cheese & 60 & 20 & $7.47 \pm 7.4$ & $6.28 \pm 6.6$ \\
\hline
\end{tabular}

ensayo de virulencia, los organismos evaluados pudieron ser aislados del bazo de los ratones empleados como testigo negativo (inoculados con solución salina fisiológica).

En el Cuadro 1 se muestra la distribución de la virulencia relativa de las cepas con relación a la fuente. Once de las cepas produjeron el mismo porcentaje de letalidad por ambas vías de inoculación, sin embargo, las cepas control (LMC1 y LMC2) y una de alfalfa (AC3) produjeron una letalidad de $100 \%$ al ser inoculadas por vía intravenosa, pero no fue así por la vía intragástrica, en donde mostraron letalidades de 0 o $20 \%$. Dos cepas (16.7\%) provenientes de alfalfa mostraron $100 \%$ de letalidad en ambas vías de inoculación y seis cepas (50 \%) no produjeron muerte en los ratones por ninguna vía de inoculación (iv o ig). Siete de las doce cepas y las dos cepas tstigo lograron invadir y crecer en el bazo de strains were recovered from the spleens of mice inoculated intravenously; however, in five mice inoculated by intragastric route this was not possible.

The diversity of levels of virulence was also reflected in the culture of cell lines J 774 and Caco-2. The intracellular cfu for each strain was determined at 2, 4, 8 and $24 \mathrm{~h}$ post infection, finding that the evaluated strains can invade and replicate inside the cells of both cell lines (Figures 1, 2). It was observed that six strains in macrophage-like cell line $\mathrm{J} 774$ (AC3, LC1, MFC1, MFC2, QC1 and QC4) and seven in cell line Caco-2 obtained from food, milk, feces and cheese showed significant differences in comparison to the control strain LMC1 ( $\mathrm{L}$. monocytogenes ATCC 43249) $(\mathrm{P}<0.05)$ with respect to rate of invasion. It was also found that in both cell lines, five strains obtained from faeces, milk and cheese (LC1, MFC1, MFC2, 
los ratones en ambas vías de inoculación con diferentes proporciones. Los ratones inoculados vía intravenosa (5.09 $\pm 1.98 \log _{10}$ ufc) y los ratones muertos (7.52 $\pm 0.41 \log _{10}$ ufc) presentaron conteos en bazo superiores respecto a los observados en los ratones inoculados vía intragástrica (3.04 $\pm 2.70 \log _{10}$ ufc) y los sacrificados ( $2.98 \pm 2.12 \log _{10}$ ufc). Todas las cepas fueron recuperadas del bazo de los ratones inoculados por la vía intravenosa, no obstante en cinco de los ratones inoculados por vía intragástrica esto no fue posible.

La diversidad de los niveles de virulencia se reflejó también en el cultivo de las cepas en las líneas celulares $\mathrm{J} 774$ y Caco-2. Se determinaron las ufc intracelulares para cada cepa 2, 4, 8 y 24 h posteriores a la infección, hallándose que todas las cepas evaluadas pueden invadir y replicarse intracelularmente en ambas líneas celulares (Figuras 1 y 2 ). Se observó que seis

Figura 1. Invasión de doce cepas de Listeria monocytogenes aisladas de cabras y sus derivados en células epiteliales Caco-2 (barras color negro) y macrófagos $\mathrm{J774}$ (barras color gris), expresadas en porcentajes respecto al inóculo

Figure 1. Invasion of 12 strains of Listeria monocytogenes isolated from goats and their by-products in epithelial cell line Caco-2 (black bars) and macrophage-like cell line $\mathrm{J} 774$ (grey bars), expressed in percentages with respect to the inoculum

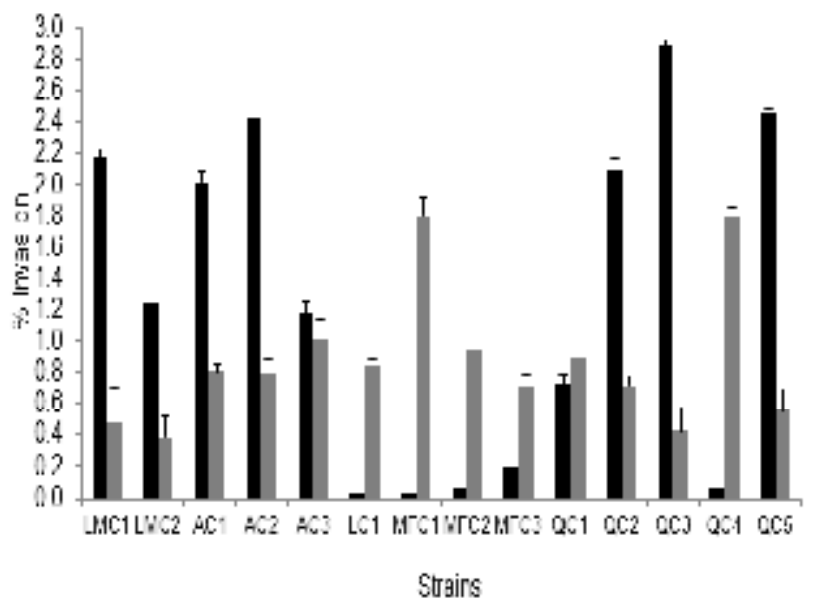

The error bars represent standard deviation of the mean
QC2 and QC4) showed significant difference in comparison to the control strain LMC1 $(P<0.05)$ in relation to intracellular growth within $24 \mathrm{~h}$. Likewise, it was observed that irrespectively of the strain, the rates of invasion and intracellular growth were lower in macrophage-like cell line

Figura 2. Crecimiento de 12 cepas de Listeria monocytogenes aisladas de cabras y sus derivados. A) Células epiteliales Caco-2, B) Macrófagos J774

Figure 2. Growth of 12 strains of Listeria monocytogenes isolated from goats and their by-products. A) Epithelial cell line Caco-2, B) Macrophage-like cell line J774
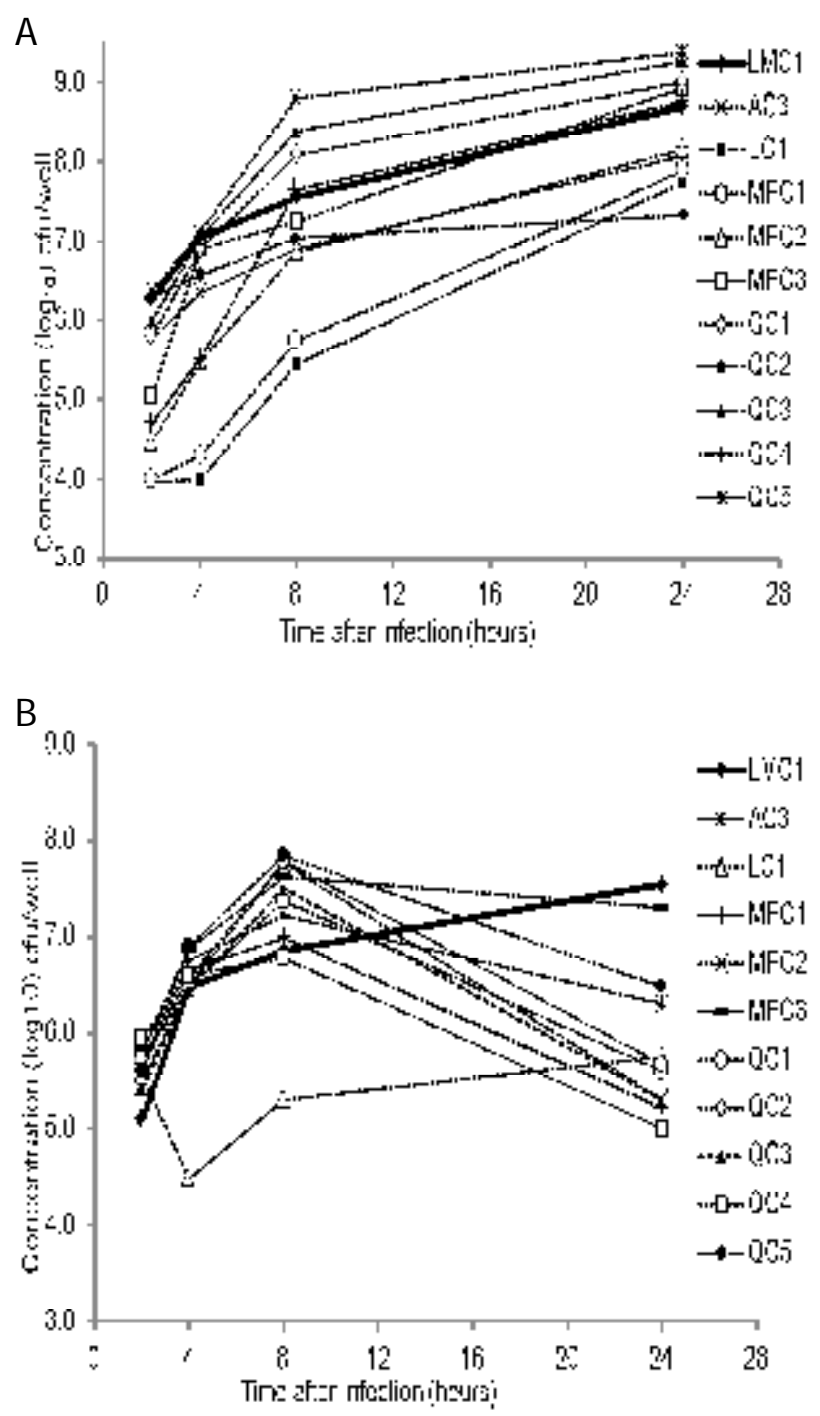

Values of cfu $(\log 10)$ recorded 2, 4, 8 and $24 \mathrm{~h}$ after infection. 
cepas en los macrófagos $\mathrm{j} 774$ (AC3, LC1, MFC1, MFC2, QC1 y QC4) y siete en las células Caco-2 (AC3, LC1, MFC1, MFC2, MFC3, QC1 y QC4) obtenidas de alimento, leche, materia fecal y queso, muestran diferencia significativa con la cepa testigo LMC1 (L. monocytogenes ATCC 43249) $(P<0.05)$ en relación al porcentaje de invasión. También se encontró que para ambas líneas celulares, cinco de las cepas obtenidas de materia fecal, leche y queso ( $L C 1, M F C 1$, MFC2, QC2 y QC4) muestran diferencia significativa con la cepa testigo LMC1 $(\mathrm{P}<0.05)$ respecto al crecimiento intracelular en $24 \mathrm{~h}$. Del mismo modo, se observó que independientemente de la cepa, los porcentajes de invasión y el crecimiento intracelular fueron menores en los macrófagos J774 (0.09 \pm $0.43 \% ; 0.65 \pm 1.07 \log _{10}$ ufc) que en las células Caco-2 (1.25 $\pm 1.07 \%$; $3.0 \pm 0.85$ $\log _{10}$ ufc) (Figuras 1 y 2 ). El crecimiento de la cepas en los macrófagos presentó una disminución entre las 8 y las 24 h posteriores a la infección, excepto $\mathrm{ACl}, \mathrm{AC2}$ y las cepas control LMC1 y LMC2 (Figura 2B). La cepa proveniente de leche (LC1) tuvo dificultades para sostener el crecimiento en los macrófagos, mostrando una disminución en las ufc $4 \mathrm{~h}$ posteriores a la infección.

Asimismo, se encontró que el modelo cuadrático de la forma logUFC $=A t^{2}+B t+C$, donde $t$ representa el tiempo, es adecuado para describir la cinética de crecimiento promedio de todos los evaluados en ambas líneas celulares $\left(r^{2} \geq 0.85\right)$. Por medio de la comparación de modelos se confrontaron las cinéticas de las cepas con el control LMC1 y se obtuvo que en Caco-2 y el los macrófagos J 774, 9 y 10 de las cepas respectivamente (AC3, LC1, MFC1, MFC2, QC1, QC2, QC3, QC4, QC5 y MFC3) presentaron diferencia significativa $(P<0.05)$ en por lo menos uno de los valores estimados de los parámetros del modelo.

Estudios llevados a cabo por el grupo de Roche et al(19) sugieren que hasta un $50 \%$ de las cepas de L. monocytogenes podrían tener una baja virulencia debido a mutaciones en determinados genes de virulencia. Otros estudios
J $774\left(0.09 \pm 0.43 \% ; 0.65 \pm 1.07 \log _{10} \mathrm{cfu}\right)$ than in cell line Caco-2 (1.25 $\pm 1.07 \%$; $3.0 \pm$ $0.85 \log _{10} \mathrm{cfu}$ ) (Figures 1, 2). Strain growth in macrophages decreased between 8 and $24 \mathrm{~h}$ after infection, except $A C 1, A C 2$ and control strains LMC1 and LMC2 (Figure 2B). The strain obtained from milk (LC1) had difficulties maintaining growth in macrophages, showing a decrease in cfu $4 \mathrm{~h}$ postinfection.

Likewise, it was found that the quadratic model of the form logCFU $=A t^{2}+B t+C$, where $t$ represents time, is adequate for describing growth rate kinetics of all the evaluated in both cell lines $\left(r^{2} \geq 0.85\right)$. By comparing the models, growth kinetics of the strains were reviewed against the control LMCl and it was observed that in epithelial cell line Caco- 2 and macrophage-like cell line J 774, nine and ten of the strains, respectively $(A C 3, L C 1, M F C 1, M F C 2$, QC1, QC2, QC3, QC4, QC5 and MFC3), showed significant difference $(P<0.05)$ in at least one of the estimated model parameter values.

Studies conducted by Roche et al(19) suggest that up to $50 \%$ of L. monocytogenes strains could have low virulence due to mutations in certain virulence genes. Other studies show that virulence of $\mathrm{L}$. monocytogenes strains varies even within the same serotype $(21,22,23)$. Although the strains evaluated in this study belonged to serotype $4 b$, which is one of the most frequently isolated in cases of listeriosis, such strains showed different levels of virulence in the assays performed.

In this study, the relative virulence of strains in $\mathrm{BALB} / \mathrm{C}$ mice was evaluated. To do so, they were inoculated by intravenous and intragastric route. The determination of relative virulence, which is expressed as percentage of lethality, represents an alternative for assays of virulence in mice, since it requires smaller number of animals per assay because it is independent of

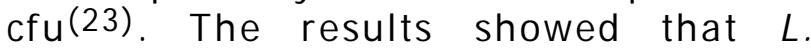
monocytogenes strains inoculated in BALB/C mice varied in percentage of lethality and in their ability to grow in the spleen of mice. It 
muestran que la virulencia de las cepas de L. monocytogenes varía incluso dentro del mismo serotipo $(21,22,32)$. A pesar de que las cepas evaluadas en este trabajo pertenecen al serotipo $4 b$ que es uno de los más frecuentemente aislados en casos de listeriosis; dichas cepas presentaron diferente nivel de virulencia en los ensayos realizados.

En este trabajo se evaluó la virulencia relativa de las cepas en ratones BALB/c, para ello fueron inoculadas por la vía intravenosa o intragástrica. La determinación de la virulencia relativa, la cual se expresa como porcentaje de letalidad, representa una alternativa para los ensayos de virulencia en ratón, ya que requiere menor número de animales por ensayo porque es independiente de las ufd(23). Nuestros resultados mostraron que las cepas de L. monocytogenes inoculadas en ratones BALB/c variaron en el porcentaje de letalidad que causan y en su habilidad para crecer en el bazo de ratón. Se encontró que la infectividad de algunas cepas fue diferente cuando se comparó la vía de inoculación. El 50 \% de las cepas no mostró virulencia en los ratones independientemente de la vía de inoculación (iv o ig) y no lograron infectar el bazo de los ratones después de inoculación intragástrica. De acuerdo con reportes, el porcentaje de cepas de L. monocytogenes no patógenas varía entre 1.6 y 90 \%(32).

En diversos trabajos se observa que la incapacidad de ciertos aislados para infectar el bazo y en general la baja virulencia de cepas de campo, podría reflejar la mutación o ausencia de uno más factores de virulencia lo cual afectaría la patogenicidad del microorganismo $(33,34)$. Aunque la cuantificación de bacteria viable en el bazo o el hígado ha provisto los resultados más consistentes en la evaluación cuantitativa de la virulencia $(35,36)$, existen trabajos que muestran una amplia variación en la infectividad en ratones, en los cuales se han obteniendo conteos promedio <3 $\log _{10}$ ufc en el bazo e hígado de ratones inoculados por la vía intragástrica(37). En el presente estudio se encontró que una cepa aislada de materia fecal was found that the infectiveness of some strains was different when compared to the inoculation route. Fifty percent of strains did not show virulence in mice, irrespective of the route of inoculation (iv or ig) and were not able to infect the spleen of mice after intragastric inoculation. According to reports, the percentage of nonpathogenic $L$. monocytogenes strains ranged between 1.6 and $90 \%(32)$.

In several studies it is observed that the inability of certain isolates to infect the spleen and overall low-virulence of field strains, could reflect mutation or absence of more than one factors of virulence, which would affect the pathogenicity of the microorganism $(33,34)$. Although quantification of viable bacteria in spleen and liver has given more consistent results in the quantitative evalualtion of virulence $(35,36)$, there are studies that show wide variations of infectivity in mice, in which average counts $<3 \log _{10}$ cfu in spleen and liver of mice inoculated by intragastric route have been obtained(37). In the present study it was found that a strain isolated from faeces (MFC3) and inoculated intravenously, produced counts in spleen similar to the obtained in dead mice (7.38 $\left.\pm 7.3 \log _{10} \mathrm{cfu}\right)$ without causing death in mice. This could indicate that a high count of microorganisms in spleen of mice inoculated by intravenous route, does not necessarily ensure virulence itself. It has been observed that the evaluation of virulence by counts in spleen after intravenous inoculation may fail to detect and isolate L. monocytogenes with low infectivity when the intragastric route is used; additionally, the majority grew better in spleen than in liver due to inoculation by intravenous route. It is believed that the route of entry of the microorganism may affect bacterial distribution in such organs, and because cellular environment of the spleen and liver differs, specific mechanisms of virulence are required for bacterial growth in each organ $(26,36)$.

A main contributor to virulence of $L$. monocytogenes is its ability to invade and replicate within a wide variety of eukaryotic 
(MFC3) inoculada por vía intravenosa, produjo conteos en bazo semejantes a los obtenidos en ratones muertos ( $7.38 \pm 7.3 \log _{10}$ ufc) sin causar muerte en los ratones. Esto podría indicar que un conteo elevado del microorganismo en el bazo de ratones inoculados por vía intravenosa, no necesariamente asegura la virulencia del mismo. Se ha observado que la evaluación de la virulencia por conteos en el bazo después de la inoculación intravenosa podría fallar para detectar aislamientos de $\mathrm{L}$. monocytogenes con poca infectividad para la ruta intragástrica, y la mayoría crecen mejor en el bazo que en el hígado debido a la inoculación vía intravenosa, por ello se cree que la ruta de entrada podría afectar la distribución de la bacteria en dichos órganos, y que el ambiente celular del bazo e hígado difiere, requiriéndose mecanismos de virulencia específicos para su crecimiento en cada uno(26,36).

Un contribuyente principal a la virulencia de $L$. monocytogenes es su habilidad para invadir y replicarse dentro de una amplia variedad de células eucariotas $(18,20)$. Las bacterias generalmente crecen de manera exponencial $(38,39)$; sin embargo en este trabajo se encontró que las cepas evaluadas de L. monocytogenes mostraron un crecimiento polinomial de segundo grado en las líneas celulares macrófagos J 774 y Caco-2. En los resultados de los ensayos in vitro, se observó que las cepas obtenidas de cabras y sus derivados difieren en su habilidad para invadir ambas líneas celulares Caco- 2 y los macrófagos, aunque mostraron el mismo potencial de crecimiento dentro de las células. En general se observó una invasividad y crecimiento intracelular ligeramente superior en las células epiteliales Caco-2, mostrando también mayor dispersión en los datos obtenidos respecto a las cepas evaluadas. Nuestros resultados de crecimiento intracelular en ambas líneas celulares concuerdan con los obtenidos en otros estudios, en los cuales las cepas de $L$. monocytogenes crecen $2-3 \log _{10}$ (10 a 12 h) en las células Caco-2, comenzando a declinar su crecimiento hacia las $24 \mathrm{~h}, \mathrm{y}$ en los cells $(18,20)$. Bacteria generally grow exponentially $(38,39)$; however, in this study, the evaluated strains of $L$. monocytogenes showed second-degree polynomial growth in macrophage-like J 774 and Caco-2 cell lines. In the results of in vitro assays, it was observed that strains obtained from goats and their byproducts differed in their ability to invade both cell lines, although they showed the same cell's growth potential. In general, a slightly higher invasiveness and intracellular growth was observed in epithelial cell line Caco-2, also showing greater dispersion in data obtained with regard to the evaluated strains. In the present study, the intracellular growth results are in accordance with the obtained in other studies, in which L. monocytogenes strains grew 2-3 $\log _{10}$ (10 to $12 \mathrm{~h}$ ) in Caco-2 cell line, starting to decline their growth at around $24 \mathrm{~h}$ and in macrophage-like cell line J 774 they grew 1.5 to $3 \log _{10}(6$ to $14 \mathrm{~h}$ ), decreasing their growth between 10 and $24 \mathrm{~h}$ post infection $(40,41)$.

The results of the in vitro assay were not possible to reproduce in the in vivo assay using intragastric inoculation in BALB/C mice. Although all evaluated strains were able to invade Caco- 2 cell line, not all were able to invade the spleen after intragastric inoculation. These results are in accordance with other studies, showing that virulence is not only determined by its ability of invasion and intracellular growth, but also by its ability to grow in vivo $(37,42)$.

Internaline $A$ is a virulence factor of $L$. monocytogenes that is necessary for the invasion of intestinal epithelium. Some low virulence serotypes (for instance, 1/2c) have mutations in inlA gene, giving place to truncated internaline $A$, but in serotype $4 b$ these mutations are not present, which has been associated with its more virulent character(43). Although $\mathrm{E}$-cadherin in mouse is not an efficient receptor for internaline $A$ of $L$. monocytogenes, the mechanism of action that involves E-cadherin, which promotes bacterial internalization in the host cell, could not be the only route, since several studies show that some mouse lineages 
macrófagos crecen 1.5 a $3 \log _{10}(6$ a 14 h), disminuyendo su crecimiento entre 10 y $24 \mathrm{~h}$ posteriores a la infección $(40,41)$.

Los resultados del ensayo in vitro no pudieron reproducirse del todo en el ensayo in vivo usando inoculación intragástrica en ratones BALB/c. A pesar de que todas las cepas evaluadas lograron invadir las células Caco-2, no todas consiguieron invadir el bazo después de la inoculación por vía intragástrica. Estos resultados concuerdan con lo encontrado en otros estudios, indicando que la virulencia no solamente está determinada por su capacidad de invasión y crecimiento intracelular, sino también por su habilidad para crecer in vivo $(37,42)$.

La internalina A es un factor de virulencia de $L$. monocytogenes necesario para la invasión de células del epitelio intestinal. Algunos serotipos poco virulentos (por ej., 1/2c) poseen mutaciones en el gen inlA que dan lugar a internalinas A truncadas, pero en el serotipo 4b no se dan estas mutaciones, lo que se ha asociado con su carácter más virulento(43). Aunque la E-caderina de ratón no es un receptor eficiente para la internalina $A$ de L. monocytogenes, el mecanismo de acción que involucra la E-caderina el cual promueve la internalización de la bacteria en la célula hospedera, podría no ser la única ruta, ya que diversos estudios muestran que algunas líneas de ratón como la BALB/c usada en este trabajo, son susceptibles a la infección vía intragástrica por L. monocytogenes $(20,43)$. Además, la habilidad de L. monocytogenes para sobrevivir en el tracto gastrointestinal e invadir a través de la mucosa, y la presencia de condiciones fisiológicas e interacciones microbianas con bacterias comensales en la mucosa intestinal, posiblemente sean factores limitantes para la infección natural, y requieran factores de virulencia diferentes de aquellos necesarios para la invasión y multiplicación de células in vitro $(29,37,44)$. Estas podrían ser algunas de las razones por las cuales los resultados de los ensayos en células humanas no siempre such as BALB/C used in this study, are susceptible to $L$. monocytogenes infection by intragastric route $(20,43)$. Also, the ability of $\mathrm{L}$. monocytogenes to survive in the gastrointestinal tract and invade through the mucosa, and the presence of physiological conditions and microbial interactions with commensal bacteria in the intestinal mucosa, are probably limiting factors for a natural infection and require virulence factors different to those necessary for invasion and multiplication of in vitro cells $(29,37,44)$. These could be some reasons for which the results of the assays in human cells not always show a clear correlation with the results obtained in the model of mice inoculated by oral route.

In the present study, two of the L. monocytogenes strains ( $\mathrm{ACl}$ and $\mathrm{AC2}, 16.7 \%$ ) caused $100 \%$ lethality in mice as consequence of intravenous and intragastric inoculation; these strains showed high concentrations of the microorganism in spleen, sustained growth in both cell lines and its kinetic parameters did not have significant difference in comparison to the control strain LMCl (ATCC 43249), which could suggest that such strains would be better able to survive in the gastrointestinal tract, reach blood trespassing the intestinal mucosa and multiply in sustained growth in macrophages, showing a decrease in intracellular growth $4 \mathrm{~h}$ post infection and, in general, lower intracellular growth in comparison to the rest of the strains in both cell lines. Non-virulent strains capable to initiate an infection inside macrophages have been found, but they are not able to extend it for at least $7 \mathrm{~h}$; this capacity has been associated with protein expression of DNA recovery and stress response. It is considered that these differences could determine the ability of L. monocytogenes to survive inside macrophages(18).

This study shows that the evaluated strains of L. monocytogenes coming from goats and their by-products, all of them serotype $4 b$, showed different virulence level in the assays performed, which is not only determined by the invasion 
muestren una correlación clara con los resultados obtenidos en el modelo de ratón inoculados por la vía oral.

En nuestro estudio dos de las cepas evaluadas de Listeria monocytogenes ( $\mathrm{ACl}$ y $\mathrm{AC2}, 16.7 \%$ ) causaron el $100 \%$ de letalidad en ratones como consecuencia de la inoculación intravenosa e intragástrica; estas cepas mostraron concentraciones altas del microorganismo en el bazo, un crecimiento sostenido en ambas líneas celulares y sus parámetros cinéticos no tuvieron diferencia significativa al compararlos con la cepa testigo LMC1 (ATCC 43249), lo cual podría sugerir que dichas cepas estarían mejor capacitadas para sobrevivir en el tracto gastrointestinal, llegar a sangre traspasando la mucosa intestinal y multiplicarse en los órganos. Asimismo, una cepa obtenida de leche de cabra fue incapaz de desarrollar un crecimiento sostenido en los macrófagos, mostrando una disminución en su crecimiento intracelular $4 \mathrm{~h}$ posteriores a la infección, y en general un crecimiento intracelular menor comparado con el resto de las cepas en ambas líneas celulares. Se han encontrado cepas consideradas avirulentas capaces de iniciar una infección dentro de los macrófagos pero no logran prolongarla por al menos $7 \mathrm{~h}$, esta capacidad ha sido asociada con la expresión de proteínas de reparación de DNA y de respuesta a estrés, y se considera que estas diferencias podrían determinar la habilidad de L. monocytogenes para sobrevivir en los macrófagos(18).

Este estudio muestra que las cepas evaluadas de L. monocytogenes provenientes de cabras y sus derivados, todas del serotipo $4 \mathrm{~b}$, presentaron diferente nivel de virulencia en los ensayos realizados, la cual no solo está determinada por la capacidad de invasión y crecimiento intracelular, sino también por su habilidad para crecer in vivo. No obstante que todas las cepas evaluadas tuvieron la capacidad para invadir y crecer intracelularmente en los macrófagos J774 y las células epiteliales Caco-2, no todas establecieron una infección y produjeron muerte en los ratones. Si bien las cepas con mayor nivel de virulencia provienen capacity and intracellular growth, but also for their ability to grow in vivo. Although all evaluated strains were able to invade and grow intracellularly inside macrophage-like cell line $\mathrm{J} 774$ and inside epithelial cell line Caco-2, not all established an infection and caused death in mice. While strains with higher virulence level come from alfalfa used as food in goats, these represent a risk for human and animal health, since they can be disseminated in the herd and from this to other exploitations or facilities where food is elaborated. Because farm ruminants and milk have been frequently involved in listeriosis cases and goats as food source are of the utmost importance, further studies of this species are needed.

End of english version

de alfalfa utilizada como alimento de cabras, estas representan un riesgo para la salud animal y la salud humana, ya que pueden ser diseminadas en el rebaño, y de éste a otras explotaciones $\mathrm{o}$ a las instalaciones donde se elaboran alimentos. Debido a la que los rumiantes de granja y la leche han sido frecuentemente implicados en casos de listeriosis y la importancia de las cabras como fuente de alimentos, es necesario incrementar la investigación en esta especie animal.

\section{AGRADECIMIENTOS}

Trabajo financiado por SAGARPA clave del proyecto 46599; CONACYT clave del proyecto SIN-2008/90945 y beca CONACYT número 173630.

\section{LITERATURA CITADA}

1. Rocourt J, Cossart P. Listeria monocytogenes. In: Doyle MP, Beuchat LR, Montville TJ editors. Food Microbiology, 
Fundamentals and Frontiers. Washington DC; ASM Press; 2000: 337-352.

2. Allerberg $F$, Wagner $M$. Listeriosis a resurgent foodborne infection, Clinical Microbiol Infect Dis 2010;16;16-23.

3. CDC. Foodborne Diseases Active Surveillance Network (FoodNet): FoodNet Surveillance Report for 2011 (Final Report). Atlanta, Georgia: U.S. Department of Health and Human Services, CDC. 2012.

4. Centers for Disease Control and Prevention (CDC). National Listeria Surveillance Annual Summary, 2011. Atlanta, Georgia: US Department of Health and Human Services, CDC, 2013

5. European Centre for Disease Prevention and Control. Annual epidemiological report on communicable diseases in Europe 2008. Stockolm: European Centre for Disease Prevention and Control, 2008.

6. European Centre for Disease Prevention and Control. Annual Epidemiological Report 2012. Reporting on 2010 surveillance data and 2011 epidemic intelligence data. Stockholm: ECDC; 2013.

7. Eilertz I, Danielsson-Tham ML, Hammarberg KE, Reeves MW, Rocourt J, Seeliger HPR, et al. Isolation of Listeria monocytogenes from goat cheese associated with a case of listeriosis in goat. Acta Vet Scand 1993; 34: 145-149.

8. McDonough PL, Wiedmann M. Ecology and transmission of Listeria monocytogenes infecting ruminants and in the farm environment. Appl Environ Microbiol 2004; 70:4458-4467.

9. Nightingale $K K$, Schukken $\mathrm{YH}$, Nightingale $C R$, Fortes ED, Ho AJ, Her Z, Grohn YT, et al. Ecology and transmission of Listeria monocytogenes infecting ruminants and in the farm environment. Appl Environ Microbiol 2004;70:4458-4467.

10. Haenlein GFW. About the evolution of goat and sheep milk production. Small Rumin Res 2007;68:3-7.

11. FAO Official statistics (FAOSTAT). The Statistics Division, Economic and Social Department. GLiPHA Global Livestock Production and Health Atlas, Animal Production and Health Division 2007. http://kids.fao.org/glipha/. Accessed Dec 3, 2013.

12. Haenlein GFW. Past, present, and future perspectives of small ruminant research. J Dairy Sci 2001;84:2097-2115.

13. Dubeuf JP, Morand-Fehr P, Rubino R. Situation, changes and future of goat industry around the world. Small Rumin Res 2004; 51: 165-173.

14. Vázquez C, Rodas O, Quiñones El. Ocurrence of Listeria species in raw milk in farms on the outskirts of México City. Food Microbiol 2001;18(2):177-181.

15. Moreno ER, García GA, Acedo FE, González RH, Call JE, Luchansky JB, Díaz CM. Prevalence, types, and geographical distribution of Listeria monocytogenes from a survey of retail queso fresco and associated cheese processing plants and dairy farms in Sonora, México. J Food Prot 2007; 70(11):2596-2601.

16. Saltijeral JA, Álvarez VB, García B. Presencia de Listeria en quesos mexicanos. J Food Saf 1999; 19(4):241-247.

17. Salas TE, Díaz AE. Aislamiento de Listeria monocytogenes en caprinos de México. Téc Pecu Méx 1988;28:92-95.

18. Donaldson JR, Nanduri B, Pittman JR, Givaruangsawat S, Burgess SC, Lawrence ML. Proteomic expression profiles of virulent and avirulent strains of Listeria monocytogenes isolated from macrophages. J Proteomics 2011;74:19061917.
19. Roche SM, Grépinet $O$, Kerouanton A, Ragon M, Leclercq A, Témoin $S$, et al. Polyphasic characterization and genetic relatedness of low-virulence and virulent Listeria monocytogenes isolates. BMC Microbiol 2012; 12:304.

20. Kuhn M, Scortti M, Vazquez-Boland JA. Pathogenesis. In: Liu D editor. Handbook of Listeria monocytogenes. Boca Ratón, FL, USA: CRC Press; 2008:97-136.

21. Kim SH, Bakko MK, Knowles D, Borucki MK. Oral inoculation of $\mathrm{A} / \mathrm{J}$ mice for detection of invasiveness differences between Listeria monocytogenes epidemic and environmental strains. Infect Immun 2004; 72:4318-4321.

22. Jaradat $Z \mathrm{~W}$, Bhunia $A K$. Adhesion, invasion, and translocation characteristics of Listeria monocytogenes serotypes in Caco2 cell and mouse models. Appl Environ Microbiol 2003; 69:3640-3645.

23. Liu D. Listeria monocytogenes: comparative interpretation of mouse virulence assay. FEMS Microbiol Lett 2004;233: 159164.

24. Ramírez BG. Estudio de Listeria monocytogenes en leche de cabra [tesis maestría]. México, DF: Universidad Nacional Autónoma de México; 2007.

25. Strassburger MM, Ramírez BG, Álvarez MCl, Tenorio GVR. Serotipificación molecular de aislamientos de Listeria monocytogenes [resumen]. Congreso internacional de inocuidad de alimentos. Pto. Vallarta, México. 2010:54.

26. Barbour $\mathrm{AH}$, Rampling $\mathrm{A}$, Hormaeche $\mathrm{CE}$. Comparison of the infectivity of isolates of Listeria monocytogenes following intragastric and intravenous inoculation in mice. Microbial Pathogenesis 1996;20:247-253.

27. Manzano M, Coccolin L, Cantón C, Comi G. A rapid method for the identification and partial serotyping of Listeria monocytogenes in food by PCR and restriction enzyme analysis. Int J Food Microbiol 1998;42:207-212.

28. Larsen CN, Nørrung B, Sommer HM, Jakobsen M. In vitro and in vivo invasiveness of different pulsed-field gel electrophoresis types of Listeria monocytogenes. Applied Environ Microbiol 2002;68:5698-5703.

29. Olier M, Fabrice P, Jean-Paul L, Charles D, Andreé R, Jean G. Assessment of the pathogenic potential of two Listeria monocytogenes human faecal carriage isolates. Microbiology 2002; 148: 1855-1862.

30. Faith NG, Kathariou S, Neudeck BL, Luchansky J B, Czuprynski C]. A P60 mutant of Listeria monocytogenes is impaired in its ability to cause infection in intragastrically inoculated mice. Microbial Pathogenesis 2007; 42:237-241.

31. R Development Core Team R: A language and environment for statistical computing. R Foundation for Statistical Computing, Vienna Austria. 2011. ISBN 3-900051-07-0, http://www. R-project. org/.

32. Van-Langendonck N, Bailly S, Tabouret M, Marly J, Pardon $P$, Velge $P$. Tissue culture assays using Caco-2 cell line differentiate virulent from non-virulent Listeria monocytogenes strains. J Appl Microbiol 1998;85:337-346.

33. Roche SM, Gracieux P, Albert I, Gouali M, Jacquet C, Martin PMV, Velge P. Experimental validation of low virulence in field strains of Listeria monocytogenes. Infect and Immun 2003; 71:3429-3436.

34. Temoin S, Roche SM, Grepinet O, Fardini Y, Velge P. Multiple point mutations in virulence genes explains the low virulence of Listeria monocytogenes field strains. Microbiology 2008; 154: 939-948. 
35. Czuprynski C], Faith NG, Steinberg $\mathrm{H}$. Ability of the Listeria monocytogenes strain Scott A to cause systemic infection in mice infected by the intragastric route. Appl Environ Microbiol 2002;68:2893-2900.

36. Kushwaha K, Muriana PM. Analysis of tissue invasiveness of adherent strains of Listeria monocytogenes by in vivo mouse assay. Int J Food Microbiol 2010;141:104-109.

37. Barbour $\mathrm{AH}$, Rampling $\mathrm{A}$, Hormaeche $\mathrm{CE}$. Variation in the infectivity of Listeria monocytogenes isolates following intragastric inoculation of mice. Infect Immun 2001; 69:4657-4660.

38. Zwietering $\mathrm{MH}$, Jongenburger $\mathrm{I}$, Rombouts $\mathrm{FM}$, van'tRiet K. Modeling of the bacterial growth curve. Appl Environ Microbiol 1990;56:1875-1881.

39. Fakruddin M, Mazumder RM, Bin-Mannan KS. Predictive microbiology: Modeling microbial responses in food. Ceylon J Science (Bio Sci) 2011;40:121-131.

40. Roberts A, Chan Y, Wiedmann M. Definition of genetically distinct attenuation mechanisms in naturally virulence- attenuated Listeria monocytogenes by comparative cell culture and molecular characterization. Appl Environ Microbiol 2005; 71:3900-3910.

41. Chatterjee SS, Hossain H, Otten S, Kuenne C, Kuchmina K, Machata S, Domann E, et al. Intracellular gene expression profile of Listeria monocytogenes. Infection Immun 2006; 74:1323-1338.

42. Roche SM, Gracieux P, Milohanic E, Albert I, VirlogeuxPayant I, Temoin S, et al. Investigation of specific substitutions in virulence genes characterizing phenotypic groups of low virulence field strains of Listeria monocytogenes. Appl Environ Microbiol 2005;71:60396048.

43. Hamon $M$, Bierne $H$, Cossart P. Listeria monocytogenes: a multifaceted model. Nature Reviews 2006;4:423-434.

44. Cotter PD, Gahan CGM, Hill C. A glutamate decarboxylase system protects Listeria monocytogenes in gastric fluids. Mol Microbiol 2001;40:465-475. 
